\title{
Uncertainty, trust and formal governance mechanism in Indonesian family SMEs
}

\author{
K Kussudyarsana1, Muhammad Halim Maimun¹, and S Soepatini1 \\ ${ }^{1}$ Departement of Management, Faculty of Business and Economics, University of Muhammadiyah Surakarta, Indonesia
}

\begin{abstract}
This paper discusses the relationship between uncertainty, trust and the application of formal governance mechanism in Indonesian family SMEs. The data were obtained through survey to 360 family firms in indonesia. This study used factor analysis to validate the construct and multiple regression analysis to examine the hypothesis. The moderation testing indicated that trust moderated the relationship between uncertainty and formal governance was negatively significant
\end{abstract}

\section{INTRODUCTION}

Small Medium enterprises are acknowledged as important business entities that contribute to the world economy (Chu, 2009). In Indonesian context, small medium enterprises (SMEs) contribute significantly to the Indonesian economy through providing job employment, export contributions, and poverty reduction (Mawardi, Choi, \& Perera, 2011; Tambunan, 2008). According to the Indonesian Ministry of Cooperation and Small scale Enterprises (2012), the number of SMEs (including micro sized) in Indonesia in 2012 was 56,539,560 and contributing $4,869,568.1$ million rupiah of gross product domestic (GDP) and employing 110,808,154 people. They represent 99.9 per cent of all enterprises. Most SMEs in Indonesia are private and family owned (Patrick, 2001).

Research related to governance in family SMEs is necessary since governance is one of essential factors that contribute to business performance (Dyer 2006; Mazzi 2011). Governance in family SMEs is also important since this mechanism "...can potentially be a value destroying or valuecreating" (Goel, Jussila, \& Ikaheimonen, 2014). Governance can make family involvement become "asset" or "liabilities" for the firms (Dyer, 2006). Assets, in one hand can increase firm's performance. Liabilities, on the other hand, can decrease firm's performance (Dyer, 2006).

One of the important governance issues in family firms is governance mechanism efficiency (Nordqvist, Sharma \& Chirico
2014). There has been many attempts to searchi efficient governance in family business literature focus on internal framework environment (Basco \& Rodriguest 2009; Memili, Chrisman \& Chua 2011). These include the investigation of ownership structure and goals' process that lead to efficiency of governance (Mazzi 2011; Nordqvist et al. 2014; Pieper, Klein \& Jaskiewicz, 2008). These issues dominate the discussion about family business' governance for long period through agency perspective (Chrisman, Chua \& Sharma 2005; Gersick \& Feliu 2014; Shukla, Carney \& Gedajlovic 2014). Nevertheless, efficiency of governance is not only resulting of internal activities but also from the interaction between firms and their environment through inter-organisational exchange (Verbeke \& Kano 2012). Recent work has recognized that formal and relational governance is important aspect in understanding governance efficiency in family firms (Calabro \& Mussolino 2011; Mustakallio, Autio \& Zahra 2002; Uhlaner, Floren \& Geerling 2007).

This study aim to investigate the connection between uncertainty, trust and governance mechanisme particularly in developing country, particularly in Indonesia. Recent literature indicates that component of relational such as trust can be substitute or complement toward formal governances (Mellewigt, Madhok \& Weibel 2007; Poppo \& Zenger 2002). Information about the substitute and complement of trust to formal governance, may become an entry point to reveal when family SMEs should apply 
relational and formal governance. Costa and Bijlsma-Frankema (2007 p.397) pointed out "low trust requires formal control and high trust allows for limited formal control. However, recent literature (Costa \& BijlsmaFrankema 2007; Poppo \& Zenger 2002 \&Mellewigt et al. 2007) discus trust and formal governance in general context without distinguishing size or types of business (family and non family business). Furthermore, the literature does not take into account the business dynamic of SMEs into the application of relational and formal governance mechanism. It leads to speculate that not only trust need to be investigated to reveal the appropriateness of the application of governance mechanism in family SMEs but also organizational complexity as impact of the dynamic of business.

\section{LITERATURE REVIEW AND HYPOTHESES}

\section{Governance mechanism}

In regards with inter-firms relationship, the increasing of exchange hazard can encourage managers to choose one of on two options: formal and relational governance. Formal governance suggests that a complete contract is appropriate to overcome the increasing of exchange risk (Sheng, Brown, Nicholson \&Poppo 2006; Zhou et al. 2008). It has been suggested that detail contract is able to handle disagreement due to the increasing of exchange risk (Barthelemy\&Quelin 2006). However, because of bounded rationality, it is impossible to make a complete contract (Geyskens et al. 2006). As a consequence, when the environment uncertainty increase, the term in contracts might no longer sufficient to govern the transactions (Carson et al. 2006).

The main function of formal contract is to protect business exchange from the opportunism (Williamson 1985) and enhancing relationship (Liu, Luo \& Liu 2009). Formal contract use written contract that specify promises or obligation for each party that involve in transaction (Lamothe \& Lamothe 2012; Poppo \& Zenger 2002). Formal contract emphasizes on "detailed, binding legal agreements that specifies the obligations and roles of both parties in relationship" (Vandaele et al. 2007 p.240). Formal contract giving direction about how future contingency could be handled (Liu, Luo
\& Liu 2009). This is in line with what Williamson (1999 p.1090) suggested "credible contracting is very much an exercise in farsighted contracting, whereby the parties look ahead, recognized hazards, and devise hazard mitigating responses thereby to realize mutual gain".

Formal governance operates under incentive and sanction mechanism (Ghoshal \& Moran 1996). Given bounded rationality and information asymmetric, principals are less likely to design perfect contract that create loophole to agents to become opportunist (Gomez-Meija et al. 2001). Because there is a potential of the economic actors to abuse their mandate, then incentive and sanction mechanism are integral parts of this mechanism (Ghoshal \& Moran 1996). Thus sanction is a tool to limit risk of economic agentsbehaviour (Ghoshal \& Moran 1998). Furthermore, economic actor will tend to be cooperate and avoid opportunistic actions if there is a clear sanction in the contractual agreement (Lubatkin et al. 2007; Poppo\& Zenger 2002). In agency theory, financial incentives are viewed as sufficient incentives to align interest of agents with interest of owners (Lubatkin, Jane, Collin \& Very 2007).

Formal governance is associated with the application of formal contract and administrative control. Formal contract use written contract that specify promises or obligation for each party that involve in transaction (Lamothe \& Lamothe 2012; Poppo \& Zenger 2002). Formal governance emphasizes on "detailed, binding legal agreements that specifies the obligations and roles of both parties in relationship" (Vandaele et al. 2007 p.240). This mechanism belief that sanction mechanism will reduce the motivation to conduct opportunistic behaviour (Ghosal \& Moran 1996). Ghosal and Moran (1996) call this mechanism as "rational control". This mechanism assumes that each party have a self interest in nature and will conduct opportunistic behaviour except parties make formal arrangement to restrict opportunism (Ghosal \& Moran 1996). Formal control emphasizes rational and calculative approach. This mechanism uses reward and sanction to control people behaviour (Ghoshal \& Moran 1996). This approach sees human being as independent entity who has a goal and capability to calculate every action to achieve their goals (Coleman 1988). 


\section{Uncertainty and formal governance mechanism}

Many scholars link the governance mechanism with external factors, in particular, uncertainty (Peng \& Jiang 2010; Peng \& Luo 2000; Zhou, Poppo \& Yang 2008; Zhou, Li, Zhao \& Cai 2003).Uncertainty arises if the situation surrounding an exchange is unpredictable. Due to this factor, contract cannot easily be specified and performance is difficult to verify (Geysken et al. 2006).Uncertainty contributes to increased transaction risk since formal contracts might cannot completely cover the situations surrounding a transaction (Zhou et al. 2008). The limitation of people to absorbs, process information and predicts information in bounded rationality- means that contracts are always incomplete in a nature and therefore lead to adaptability problems related to environmental uncertainty (Carson et al. 2006). Uncertainty also leads to renegotiation of contracts and the searching new business partners that are associated to cost of transactions (Crook et al. 2013).

Uncertainty encompasses three dimensions: volume uncertainty, technology uncertainty and behavioural uncertainty (Crook et al. 2013). Volume uncertainty refers to the difficulty in predicting the availability of product required for transactors, technological uncertainty refers to the extent to which current technology will become obsolete due to technologically advancement (Arranz\&Arroyabe 2011). Behavioural uncertainty refers to the difficulty in evaluating performance of product delivered (Vandaele et al. 2007).

Many discussions about uncertainty and governance mechanism are located in area inter-firms relationship. In inter-firms relationship the main consequence of uncertainty adaptation problems (Geyskens et al. 2006). An existing contract may not cover unanticipated situations surrounding the exchange (Noorderweir et al.1997). This means that contract cannot easily be specified and performance is difficult to verify (Geyskens et al. 2006). The limitation of people to absorbs, process information and predicts information in -bounded rationalitymeans that contracts are always incomplete in a nature and therefore lead to adaptability problems related to environmental uncertainty (Carson et al. 2006). High levels of uncertainty increases the costs of adapting the contractual agreement (Rindfleisch \& Heide 1997). Uncertainty also leads to renegotiation of contracts and the searching new business partners that are associated to cost of transactions (Crook et al. 2013). Neoclassical approach suggests that the extensive contract is appropriate for responding uncertainty (Carson et al. 2006). Conversely, sociological approach view that emphasis on relational mechanism is appropriate to deal with uncertainty. The main idea is that social enforcement can mitigate against opportunism and facilitate cooperative behaviour (Carson et al. 2006).

Pollak (1985) suggest that family firms are appropriate to implement family governance or relational governance when the uncertainty that refers to complexity is low. Similarly, Gedajlovic et al. (2004) suggests that when environment becomes more complex, organisation are required to adopt formal governance by implementing formal routines and coordinating their main activities. Formal routines and coordination are most suitably carried out by specialists and professionals hired to handle complex organisational tasks. It has been suggested that uncertainty leads to authority delegation (Miller 1992).

H1: A positive relationship exist between uncertainty and the application of formal governance in family SMEs

\section{Trust in inter-firm relationships}

In one definition, trust refers to "the expectation that another organization can be relied on to fulfil its obligations, to behave in a predictable manner and to act and negotiate fairly evenly when the possibility of opportunism is present"(Gulati, Ranjay \& Nickerson 2008, p. 167). Trust in business generally refers to the "expression of confidence between the parties in an exchange" (Jones \& George 1998, p. 531). Mayer, Davis \& Schoorman (1995 p.172) propose the definition of trust as "individual willingness to be vulnerable to the actions of another party based on the expectation that the other will perform a particular action important to the trustor, irrespective of the ability to monitor or to control that other party". People trust others because they expect that others will behave in a particular way (Mayer et al. 1995) that produces the favourable outcome (Cristina Costa \& Bijlsma-Frankema 2007). 
Family firms have been associated with a high level of trust within the organization (Corbetta \& Salvato 2004; Eddleston et al. 2010). Special relationships based on blood and love (Kepner 1983), similarity of "family identity" (Zellweger et al. 2011) and "language" (Davis, Allen \& Hayes 2010) encourage trusting relationships in family firms. The long term relationship among family members also creates trust in family firms (Eddleston et al.2010). The internal relationships within families, characteristized by "face to face interaction, positive affection, mutual support and altruistic feeling among family members" (Zellwegger et al. 2011 p.5), potentially facilitates trusting relationships in family firms.

Trust in family firms is the result of the extension of social interactions within the families (Steier \& Muenthel 2014). Social interaction in families inherently cultivates trusting relationship since they have special relationships based on blood and love (Kepner 1983), similarity of "family identity" (Zelwegger et al. 2011) and "language" (Davis, Allen \& Hayes 2010). Building trust is part of the affection process that begins in infancy as parents (or other primary caregivers) care for and provide the needs of young children for food, warmth, comfort, love, security, and human response (Bubolz 2001). In family firms, trust is an essential basis for cooperation and provides firms competitiveness (Steier 2001). Trust is important in family firms since it stimulates cooperation within and between firms. As Steier and Muenthel 2014 (p.498) note " familial trust provides an essential lubricant that facilitates exchange relationship". Trust can be transferred from family affiliations to the work environment, and through the development of personal relationships into business exchanges (Salvato \& Melin 2008).

The relationship between firm and their stakeholder often rely on trust rather than formal contract (Gedjalovic \& Carney 2010; Memili et al. 2011a; Verbeke \& Kano 2010).Connections between family firms and their suppliers and customers are often stronger and more valuable those of nonfamily firms (Lyman 1991). A good relationship with other stakeholder can produce bridging social capital (Gedjalovic and Carney 2010). Family firm can built relationships with other parties whom they did not know previously, through current connections. A good connection between family firms and stakeholder is often connected with stakeholder efficiencies (Aronoff \& Ward 1995).

Trust has been acknowledged as an essential element in cooperation between individuals, groups and organizations (Gambetta 1988; Jones \& George 1998; Zaheer, McEvily \& Peronne 1998; Fulmer \& Gelfand 2012). The success of any form of collaboration needs a minimum level of trust (Costa \& Bijlsma-Frankema 2007). When people working together, the outcome cooperation is not only depend on one party's performance but also others parties' performance (Mayer, Davis \& Schoorman 1995). Therefore, they need to trust one another. However, people cannot ensure that business partners will always behave in ways that are in line organizational goals, therefore, trust is risky (Das 1998). Even though trust is associated with risk taking behaviour, people may decide to collaborate because they have confidence in the future prospect of collaboration (Das \&Teng 1998).

In economic exchange, when people trust one another, they do not need formal control to ensure that the other party will not engage misconduct behaviour (Mellewigt, Madhok \& Weibel 2007a; Puranam, P. \& Vanneste, B. S. 2009). In relationship exchange, trust minimizes coordination complexity and conflicts due to the future uncertainty and bounded rationality that inevitable exist (Gulati et al. 2005; Puranam \& Vanneste 2009). High levels of trust, do not only decrease the need to monitor performance, but also eliminate the need to use a system control based on a short term performance orientation that does not support innovation and cooperation (Hosmer 1995).

Literature suggests that in the situation where people have a low trust towards formal institutions, as in Indonesia, personal relationships are more likely to be used to reduce uncertainty (Rademakers 1998). In addition, by relying on relational ties with Indonesian state officers, for instance, people can get facilities that can only be accessed by limited persons (Rademakers 1998). This is because state officers have the authority to manage rules of the game that favour their business partners (Rademakers 1998). Rademaker (1998) also found that in Javanese business, authority is located and centralized into a person. Because of strong personal influence, informality is more salient than formality in business relationships. Because of this tendency, personal 
relationship with is more relevant rather than contract, formal procedures, and formal rules.

Some scholars indicate that level of trust (Mellewigt, Madhok \& Weibel 2007b; Poppo \& Zenger 2002) can be used to signal the application of the governance mechanism. In economic exchange, when people trust one another, they are less likely to use formal controls to assure that the other party will not engage in misconduct (Mellewigt, Madhok \& Weibel 2007b; Puranam, P. \& Vanneste, B.S. 2009). High levels of trust have been connected with the low intention to use formal governance mechanisms (Mellewigt, Madhok \& Weibel 2007b; Poppo \& Zenger 2002).

Adam \& Tisdell (2008) conducted research about inter-firm cooperation among small-medium enterprises (SMES) in the garment industry in Bandung, Indonesia. They found that trust and competency are essential factors that promote cooperation in inter-firm relationships. Trustworthy and competent partners encourage firms to maintain long-term relationships. They found that inter-firm relationships increased capabilities in marketing and production and reduced transaction costs. They reported that continuity of business cooperation is found among firms that initially use repeated business contacts and family connections.

H2: The relationship between uncertainty and formal governance is weaker when high trust exists

\section{METHODS}

Data collection was conducted from November 2013 until January 2014 through questionnaires which were hand delivered to family business owners or managers of family SMEs. Research assistants visited respondents and help them fill out structured questionnaires, since not all family business owners have good literacy and understanding about business terminology. Before respondents filled out the questionnaires, consent forms were given to respondents. The process of filling out the questionnaires took between 50-70 minutes on average. Data collected by research assistants were cross checked by researchers to ensure the questionnaires were completed. In the case where questionnaires were not completed, research assistants contacted respondents through phone calls and asked respondents to address the missing questions.

This study follows a quantitative research approach in which data were coded, calculated and quantified in order to understand the concepts represented (Creswell 2009). Quantitative research emphasizes the examination of relationships between variables that function to test the objective of theories (Creswell 2002).

This study adopts a positivist view as a research paradigm. The positive paradigm views that reality exists and follows a natural law (Neuman 2014). In administering the survey, researchers asked the same questions to many respondents (Neuman 1997, p.250). From the data collected from the survey samples the researcher is able to make generalizations about the characteristics of the population (Creswell 2009). Survey is an efficient method because it reaches a high number of respondents in a limited time (Neuman 2014).

\section{RESULTS AND DISCUSSION}

The definition of trust in this research refers toMayer, Davis, \& Schoorman (1995) and Zaheer dan Venkatraman (1995). Meyer et

Table 1.

Items in trust measurement

\begin{tabular}{lccc}
\hline \multicolumn{1}{c}{$\begin{array}{c}\text { Questions } \\
\text { Trust }\end{array}$} & Loading Factors & Cronbach & Likert Scale \\
\hline $\begin{array}{l}\text { Our enterprise and supplier(s) share mutual } \\
\text { trust }\end{array}$ & 0.734 & & $\begin{array}{c}\text { 1=Do not agree } \\
\text { at all }\end{array}$ \\
$\begin{array}{l}\text { In decision making, our enterprise and } \\
\text { supplier(s) are concerned about each other }\end{array}$ & 0.583 & & \\
interests & & \\
$\begin{array}{l}\text { Our enterprise and our selected buyers } \\
\text { have mutual trust }\end{array}$ & 0.744 & \\
$\begin{array}{l}\text { In decision making, our enterprise and } \\
\text { selected buyer(s) are concerned about each } \\
\text { other interests }\end{array}$ & 0.729 & \\
$\begin{array}{l}\text { The people in our enterprise are honest and } \\
\text { truthful }\end{array}$ & 0.34 & \\
& & & \\
\hline
\end{tabular}


Table 2.

Testing for Moderation effect of Trust

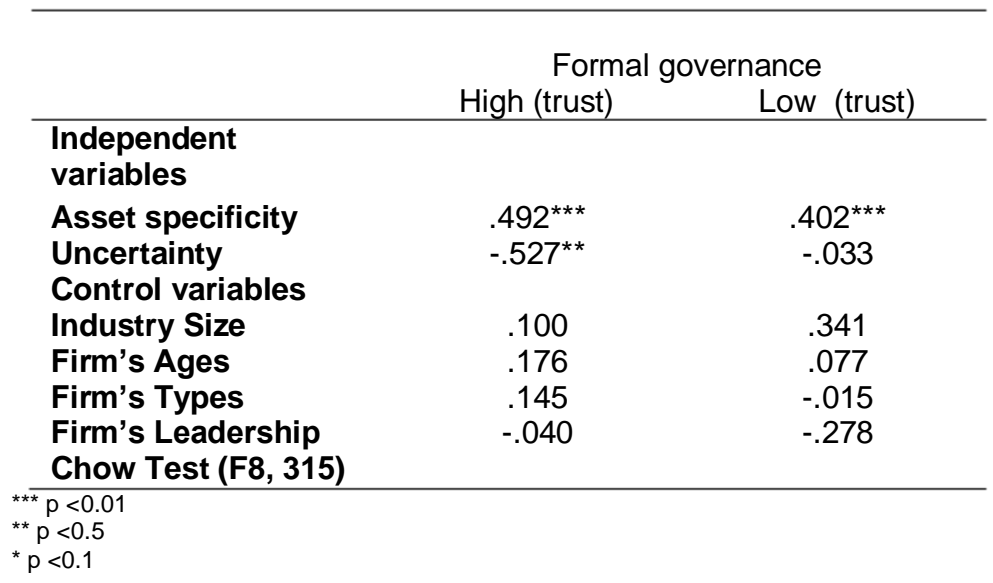

al. (1995) define trust as "an individual willingness to be vulnerable to another party and the expectation that an exchange partner will not behave opportunistically even when such behaviour cannot be detected" (p. 712). While in contrast to Zaheer and Venkatraman who focus solely on the inter-organizational relationship dimension of trust, this research also looks within firms. This research used the instrument of trust from (Zaheer \& Venkatraman 1995). The score of Cronbach Alpha in this construct was 0.751 .

This study predicts that the effect of asset specificity, uncertainty and formal governance is moderated by level of trust. The different situations of trust will have consequences on the relationship between asset specificity, uncertainty and governance mechanism. When the level of trust is low, the relationship between asset specificity, uncertainty and governance mechanism is strong. Conversely, when the level of trust is high, the relationship between asset specificity and uncertainty on formal governance is weak.

To test a moderating variable, this study follows procedural testing suggested by Lee \& Cavusgil (2006) that was adopted from Sharma et al (1981). According to Lee \& Cavusgil (2006), to test moderating variables, data are separated into two groups based on the level of attribute of moderator variable (low-high) and then were regressed. Next, a Chow Test was employed to test differences of regression analysis between two groups. If the differences between the two regression analyses is significant, we may conclude that the factor that made the difference is the moderating variable.
Hypothesis $\mathrm{G}$ and $\mathrm{H}$ predicts trust as a moderating variable.

$$
\begin{aligned}
& \mathrm{Y}_{1}=a+b_{11} \mathrm{X}_{11}+b_{12} \mathrm{X}_{12}+b_{13} \mathrm{X}_{13}+\varepsilon_{\mathrm{i}} \\
& \mathrm{Y}_{2=} \alpha+b_{12} \mathrm{X}_{21}+b_{22} \mathrm{X}_{22}+b_{32} \mathrm{X}_{32}+\varepsilon_{\mathrm{i}}
\end{aligned}
$$

and then Chow test is conducted to test the difference of regression analysis.

Chow test formula :

$$
\mathrm{F}=\frac{\mathrm{RSSC}-(\mathrm{RSS} 1+\mathrm{RSS} 2) / \mathrm{k}}{(R S S 1+R S S 2) /(n-2 k)}
$$

$\mathrm{RSSc}=$ Residual sum square combination

RSS1 = Regression analysis 1

RSS2 = Regression analysis 2

$\mathrm{n}=$ sample size

$\mathrm{k}=$ parameter

The result showed the difference influence of uncertainty on formal governance in high and low trust situation. When trust was high, uncertainty has negative and significant impact on formal governance $(p<0.5, t=-$ 2.372). In contrast, when trust was low, uncertainty has no significant impact on formal governance $(p>0.5, t=-0.150)$. Bases on this result, trust moderate relationship between uncertainty and formal governance. Whilst, the result demonstrated that there was no different influence of asset specificity on formal governance in high and low trust situation. Asset specificity has significantly impact on both high and low trust situation. Similar result was found for relational governance. When the level of trust was high, uncertainty has negatively significant impact on relational governance $(p<0.01, t=-2.93)$. But, when the level of trust was low, uncertainty did not have significant impact to relational governance $(p>0.5 t=-.613)$.

Formal governance:

RSS entire $=172.556$

$\mathrm{RSS} 1=89.119$

RSS2 $=110.365$ 
RSS entire $=89.119+110.365=199.484$

$\mathrm{F}=\frac{172.556-(89.119+110.365) / 3}{(199.484) /(314-6)}$

$=\frac{172.556-(199.484) / 3}{199.48 / 309}$

$=\frac{172.56-66.49}{0.65}$

$=163.18$

$\mathrm{F}$ table, $\alpha=5 \%, F(3, \infty)=8.53$

The result of Chow-Test indicates that the $F$ test (163.18) was bigger than $F$ table (8.53). The moderation testing indicates that trust moderate the relationship between uncertainty and formal governance. In the high trust situation, the impact of uncertainty on formal governance was negatively significant. It means that when people have high trust, firms who transact in uncertainty environment have less required formal governance.

This result bring us to the on going discussions about the relationship between trust and formal control. The first issue is about substitute and complementary between trust and formal control (Poppo \& Zenger 2002; Costa and Bijlsma-Frankema 2007). In substitution point of view, trust is opposite with formal control (Costa and BijlsmaFrankema 2007). Low trust leads to high formal control. In contrast, high trust wil bring to low formal control. Costa (2003) found that trust positively related with cooperative behavior among teamwork and negatively related with monitoring activities of teamwork members that demonstrating trust as substitute of formal control. In complementary views, trust can strengthen formal control (Mellewigt et al. 2007; Sitkin, 1995). Formal control can enhance trust to the level that enabling parties to make cooperation between them (Mellewigt et al. 2007).

The second issue about direct and indirect effect of trust on formal governance. In contrast to mainstrem that divide the relationship of trust and control as substitute and complementary, Mellewigt et al. (2007) suggested that trust is moderate the connection between asset specificity and complexity of contract. According to Mellewigt et al. (2007), the relationship between of contractual complexity and asset specificity will be weaker when trust is high. Almost the same, this research posit that trust will moderate the connection between asset specificity and formal governance. However, the result shows that asset specificity lead to the application of relational and formal governance. Thus complementary effect of trust and formal governance is more salient rather than moderation effect.

\section{CONCLUSION}

This study found that uncertainty was a determinant for governance mechanism used in family SMEs. It means that a combination of formal and relational governance is a major respond uncertainty for SMEs in Indonesia. This research also indicates that trust moderate relationship between uncertainty and formal governance. It can be seen from fact that the difference influence of uncertainty on formal governance in high and low trust situation. When trust was high, uncertainty has negative and significant impact on formal governance.

\section{REFERENCES}

Adam, L., \& Tisdell, C. (2008)Economic Theory, Applications and issues. Queensland : University of Queensland.

Arranz, N.,\& de Arroyabe, J. C. F (2012) Effect of Formal Contracts, Relational Norms and Trust on Performance of Joint Research and Development Projects.British Journal of Management, 23(4), 575-588.

Aronoff, C. E.,\& Ward, J. L. (1996) Family Business Governance: Mazimizing Family and Business Potential (5th ed.). Georgia : Family Enterprise.

Baker, G., Gibbons, R.,\& Murphy, K. J.(2002) Relational Contracts and the Theory of the Firm. The Quarterly Journal of Economics, 117(1), 39-84.

Barthélemy, J.,\& Quélin, B. V.(2006) Complexity of Outsourcing Contracts and Ex PostTransaction Costs: An Empirical Investigation.Journal of Management Studies, 43(1), 1175-1797.

Basco, R.,\& Rodriguez, M. J.(2009) Studying the family enterprise holistically. Family Business Review, 22(1), 82-95.

Bubolz, M. M.(2001) Family as source, user, and builder of social capital. Journal of SocioEconomics. 30(1),. 129-131.

Calabro, A., \& Mussolino, D (2011) How do boards of directors contribute to family SME export intensity? The role of formal and informal governance mechanisms. Journal of Management \& Governance, 17(2), 363-403

Carson, S. J., Madhok, A.,\& Wu, T.(2006) Uncertainty, opportunism, and governance: the effects of volatility and ambiguity on formal and relational contract. Acad Manage J 2006, 49, 105877.

Carney, M.,\& Gedajlovic, E.(2001) Corporate Governance and Firm Capabilities: A 
Comparison of Managerial, Alliance, and Personal Capitalisms. Asia Pacific Journal of Management, 18, 335-354.

Chrisman, J. J., Chua, J. H.,\& Sharma, P.(2005) Trends and directions in the development of a strategic management theory of the family firm. Entrepreneurship Theory and Practice, 29(5), 555-579.

Chu, W.(2009) The influence of family ownership on SME performance: evidence from public firms in Taiwan.Small Business Economics, 33(3), 353-373.

Corbetta, G.,\& Salvato, C.(2004) Self-serving or self-actualizing? Models of man and agency costs in different types of family firms: A commentary on "Comparing the agency costs of family and non-family firms: Conceptual issues and exploratory evidence. Entrepreneurship Theory and Practice, 28, 355-362.

Creswell, J. (2002) Educational Research: Planning, Conducting, and Evaluating Quantitative and Qualitative Research (1st ed.). London: Prentice Hall London.

Creswell, J. (2009) Editorial: Mapping the field of mixed methods research', Journal of Mixed Methods Research. 3(2), 95-108.

Crook, R., Combs, G. J., Ketchen, D.,\& Aguinis, H.(2013)Organizing around transaction cost what have we learned and where do we go from here.Academy of Management Perspectives, 27(1), 63-79.

Costa, A. C.,\& Bijlsma-Frankema, K (2007) 'Trust and Control Interrelations: New Perspectives on the Trust Control Nexus. Group \&amp; Organization Management, 32(4), 392-406.

Das, T. K., \& Teng, B. S.,(1998) 'Between trust and control: developing confidence in partner cooperation in alliances', Academy of Management Review.23(3), 491-512.

Davis, J. H., Allen, M. R.,\& Hayes, H. D.(2010) Is Blood Thicker Than Water? A Study of Stewardship Perceptions in Family Business. Entrepreneurship Theory and Practice, 34(6), 1093-1116.

Dyer, W. G.(2006) Examining the "family effect" on firm performance. Family Business Review, 19(4), 253-273.

Eddleston, K., Chrisman, J. J., Steier, L.,\& Chua, J. H.(2010) Governance and Trust in Family

Firms:

An Introduction. Entrepreneurship Theory and Practice, 1042-2587.

Ferguson, R. J., Paulin, M.,\& Bergeron, J.(2005) Contractual governance, relational governance, and the performance of interfirm service exchanges: the influence of boundary-spanner closeness. Journal of the Academy of Marketing Science, 33, 217-234.

Ferguson, R. J., Paulin, M., Möslein, K.,\& Müller, C.(2005) 'Relational governance, communication and the performance of biotechnology partnerships. Journal of Small Business and Enterprise Development, 12(3), 395-408.

Gedajlovic, E.,\& Carney, M.(2010) Markets, hierarchies and families: Toward a transaction cost theory of the family firm. Entrepreneurship Theory and Practice, 34, 1145-1171.

Gedajlovic, E, Lubatkin, MH \& Schulze, WS 2004, 'Crossing the treshold from founder management to professional management: A governance perspective', Journal of Management Studies, vol. 41, no. 5, pp. 899-912.

Gersick, K. E.,\& Feliu, N.(2014) Governing the family enterprise. The SAGE Handbook of Family Business, 196-225

Geyskens, L., Steenkamp, J. B.,\& Kumar, N.(2006) Make, buy, or ally: A transaction cost theory metaanalysis.Academy of Management Journal, 49, 519-543.

Ghoshal, S.,\& Moran, P.(1996) Bad for Practice: A Critique of the Transaction Cost Theory. The Academy Of Management Review, 21(1), 13-47.

Ghoshal, S.,\& Moran, P.(1996) Value creation by firms. Academy of Management Journal, 1996(1), 41-45.

Goel, S., Jussila, I.,\& Ikaheimonen, T.(2014) Governance in family firms. The SAGE Handbook of Family Business, 226-231.

Granovetter, M.(1985) 'Economic action and social structure. American Journal of Sociology, 91(3), 481-510.

Gulati, R., Lawrence, P.R.,\& Puranam, P.(2005) Adaptation in vertical relationships: Beyond incentive conflict. Strategic Management Journal, Forthcoming.

Gulati, R.,\& Nickerson, J. A.(2008) 'Interorganizational Trust, Governance Choice, and Exchange Performance. Organization Science, 19(5), 688-708.

Guthrie, D.(2001)Dragon in a three-piece suit: The emergence of capitalism in China. Princenton: Princeton University Press

Goméz-Mejía, L. R., Núnez-Nickel, M.,\& Guiterrez, I.(2001) The role of family ties in agency contracts.Academy of Management Journal, 44, 81-95.

Hosmer, L. T.,(1995) Trust: The connecting link between organizational theory and philosophical ethics.Academy of Management Review, 20(2), 379-403.

Jones, G. R.,\& George, J. M.(1998) The Experience and Evolution of Trust: Implications for Cooperation and Teamwork.Academy of Management Review, 23(1), 531-546.

Kepner, E.(1983) The family and the firm: A coevolutionary perspective.Organizational Dynamics, 12, 57-70.

Lee, Y.,\& Cavusgil, S. T.(2006) Enhancing alliance performance: The effects of contractual- 
based versus relational-based governance.Journal of Business Research, 59, 896-905

Liu, Y., Luo, Y.,\& Liu, T.(2009) Governing buyersupplier relationships through transactional and relational mechanisms: Evidence from China.Journal of Operations Management. 27(4), 294-309.

Madhok, A.(1995) Revisiting Multinational Firms' Tolerance for Joint Ventures: A TrustBased Approach. Journal of International Business Studies, 26(1), 117-137.

Memili, E., Chrisman, J. J.,\& Chu, J. H. (2011) Transaction Costs and Outsourcing Decisions in Small-and Medium-Sized Family Firms. Family Business Review, 24(1), 47-61.

Mazzi, C.(2011) Family business and financial performance: Current state of knowledge and future research challenges. Journal of Family Business Strategy,. 2(3), 166-181.

Mellewigt, T., Madhok, A.,\& Weibel, A.(2007) Trust and formal contracts in interorganizational relationships - Subtitutes and complements.Managerial and Decision Economics, 28, 833-847.

Miller, D.(1992) Environmental Fit versus Internal Fit.Organization Science, 3(2), 159-178.

Mustakallio, M., Autio, E.,\& Zahra, S.(2002) Relational and Contractual Governance in Family Firms: Effects on Strategic Decision Making.Family Business Review, 15(3), 205-222.

Neuman, L.(2014)Social Research Methods: Qualitative and Quantitative Approaches.London : Allyn and Bacon.

Neuman, L. W . (1997)Social research methods: qualitative and quantitative approaches. London: Allen and Bacon

Noordewier, T. G., John, G.,\& Nevin, J. R.(1990)Performance Outcomes of Purchasing Arrangements in Industrial Buyer-Vendor Relationships. Journal of Marketing, 54(4), 80-93.

Nordqvist, M., Sharma, P.,\& Chirico, F (2014) Family Firm Heterogeneity and Governance: A Configuration Approach.Journal of Small Business Management, 52(2), 192-209.

Patrick, H.(2001)Corporate Governance and the Indonesian Financial System: $A$ Comparative Perspective APEC New York City : Study Center Columbia Business School

Peng, M. W.(2003) Institutional transitions and strategic choices. Academy of Management Review, 28(2),275-296.

Peng, M. W.,\& Jiang, Y.(2010) Institutions Behind Family Ownership and Control in Large Firms.Journal of Management Studies, 47(2), 253-273.

Peng, M. W.,\& Luo, Y.(2000) Managerial Ties and Firm performance in a transaction economy: the nature of a micro-macro link. Academy of Management Journal, 43, 486-501.

Pieper, T. M., Klein, B.,\& Jaskiwicz, P.(2008) The Impact of Goal Alignment on Board Existence and Top Management Team Composition: Evidence from FamilyInfluencedBusinesses. Journal of Small Business Management, 46(3), 372-394.

Pollak, R. A.(1985) A transaction cost approach to families and households. Journal of Economic Literature, 23, 581-608.

Poppo, L.,\& Zenger, T.(2002) Do formal contracts and relational governance function as substitutes or complements?. Strategic Management Journal, 23(8), 707-725.

Puranam, P.,\& Vanneste, B. S.,(2009) Trust and governance: Untangling a tangled web.Academy of Management Review, 34(1), 11-31.

Rademakers, M. F. L.(1998) Market organization in Indonesia: Javanese and Chinese family business in the jamu industry.Organization Studies, 19(6), 1005-1027.

Rindfleisch, A.,\& Heide, J. B.(1997)Transaction cost analysis: Past, present, and future applications. Journal of Marketing Research, 61, 30-54.

Salvato, C.,\& Melin, L.(2008) Creating Value Across Generations in Family-Controlled Businesses: The Role of Family Social Capital.Family Business Review, 21(3), 259-276.

Sheng, S., Brown, J. R., Nicholson, C. Y.,\& Poppo, L.(2006) Do exchange hazards always foster relational governance? An empirical test of the role of communication. International Journal of Research in Marketing, 23(1), 63-77

Steier, L.(2001) Family firms, plural forms of governance, and the evolving role of trust. Family Business Review, 14(4), 353-367.

Steier, L.,\& Miriam, M.(2014) Trust in Family Business, in L Melin, M Nordqvist \& $P$ Sharma (eds), SAGE Handbook of Family Business, SAGE, Singapore.

Shukla, P. P., Carney, M.,\& Gedajlovic, E.(2014) Economic Theories of Family Firms. The SAGE Handbook of Family Business. Los Angeles :SAGE.

Tambunan, T.(2008) SME development, economic growth, and government intervention in a developing country: The Indonesian story.Journal of International Enterpreneurship, 6(4), 147

Uhlaner, L., Floren, R. H.,\& Geerlings, J.(2007) Owner Commitment and Relational Governance in the Privately-Held Firm: An Empirical Study.Small Business Economics, 29(3) 275-93

Uzzi, B.(1997) Social structure and competition in interfirm networks. Administrative Science Quarterly, 42(1), 35. 
Uzzi, B.(1997) Social structure and competition in interfirm networks: The paradox of embeddedness. Administrative Science Quarterly, 42(1), 35-67.

Vandaele, D., Rangarajan, D., Gemmel, P., \& Lievens, A. (2007) How to govern business services exchanges: Contractual and relational issues. International Journal of Management Reviews, 9(3), 237-258.

Verbeke, A.,\& Kano, L.(2010) Transaction cost economics (TCE) and the family firm.Entrepreneurship Theory and Practice, 34(6), 1173-1182

Verbeke, A., \&Kano, L.(2012) The Transaction Cost Economics Theory of the Family Firm: Family-Based Human Asset Specificity and the Bifurcation Bias.Entrepreneurship Theory and Practice, 36(6), 1183-1205.

Williamson, O. E.(1981) The Economics of Organization: The Transaction Cost Approach.American Journal of Sociology, 87, 548-577.

Williamson, O. E.(1996)The Mechanisms Of Governance. New York : Oxford University Press

Williamson, O. E. (1985) The Economic Institutions of Capitalism. New York :Free Press.
Williamson, O. E. (1985) The economic of governance. New York: Free Pass.

Wijaya, Y.(2007) The Prospect Of Familism in The Global Era: A Study On The Recent Development Of The Ethnis-Chinese Business, with Particular Attention To The Indonesian Context.Journal of business Etnics, 79, 311-317.

Zaheer, A.,\& Venkatraman, N.(1995) Relational governance as an interorganizational strategy: an empirical test of the role of trust in economic exchange.Strategic Management Journal, 16, 373-392.

Zellweger, T. M., Nason, R. S., Nordqvist, M.,\& Brush, C. G.(2011) Why Do Family Firms Strive for Nonfinancial Goals? An Organizational Identity Perspective.Entrepreneurship Theory and Practice, 37(2), 229-248.

Zhou, K. Z., Poppo, L.,\& Yang, Z.(2008) Relational ties or customized contracts? An examination of alternative governance choices in China. Journal of International Business Studies, 39(3), 526-534.

Zhou, X., Li, Q., Zhao, W.,\& Cai, H.(2003) Embeddedness and Contractual Relationships in China's Transitional Economy.American Sociological Review, 68(1), 75-102. 